\title{
New record of the sea anemone Kadosactis antarctica (Carlgren, 1928): re-description of an Antarctic deep-sea sea anemone, and a discussion of its generic and familial placement
}

Received: 11 October 2004/ Revised: 16 June 2005/ Accepted: 24 June 2005 / Published online: 3 September 2005

(C) Springer-Verlag and AWI 2005

\begin{abstract}
Sagartiogeton antarcticus Carlgren, 1928 is an Antarctic deep-sea species of sea anemone only known from its holotype. The species has been assigned to the genera Sagartiogeton and Kadosactis, and is currently placed within the family Kadosactidae Riemann-Zürneck, 1991. Kadosactis antarctica is re-described based on 11 specimens collected during the cruise of the $\mathrm{R} / \mathrm{V}$ Polarstern ANT XIX/3 (ANDEEP-I) to the Scotia Sea and off the South Shetland Islands (Antarctica). The description includes a complete account of cnidae and photographs. Because the mesogloea is thickened on the aboral surface on the base of the tentacles, this feature becomes a generic character of Kadosactis rather than a differential specific character among the species of the genus as previously proposed. Furthermore, the known distribution of the species is enlarged to include the southern branch of the Scotia Sea.
\end{abstract}

Keywords Kadosactis Kadosactidae $\cdot$ Sagartiogeton Actiniaria $\cdot$ Deep-sea $\cdot$ South Shetland Islands

\section{Introduction}

The modern classification of sea anemones is largely based on Carlgren's (1949) survey of the Actiniaria.

Communicated by H.-D. Franke

\footnotetext{
E. Rodríguez ( $\varangle)$

Departament de Biologia Marina i Oceanografia, Institut de Ciències del Mar, CMIMA (CSIC), Passeig Marítim de la Barceloneta, 37-49, 08003 Barcelona, Spain

E-mail: fani@us.es

Fax: + 34-954-233480

P. J. López-González · E. Rodríguez

Departamento de Fisiología y Zoología,

Facultad de Biología, Biodiversidad y Ecología

de Invertebrados Marinos, Universidad de Sevilla,

Reina Mercedes 6, 41012 Sevilla, Spain

E-mail: pjlopez@us.es
}

Other proposals for grouping the infraordinal categories of actiniarian sea anemones have been made (Stephenson 1920-1922; Schmidt 1972, 1974), but these have not been followed.

Carlgren (1949: 42) grouped all families of sea anemones with acontia within the subtribus Acontiaria. Carlgren himself (1949: 42) recognized its heterogeneity, but justified it for practical reasons. The acontia are believed to have evolved once and have been modified and reduced independently on several occasions (Stephenson 1920; Riemann-Zürneck 1991). However, this possibility is not taken into account in Carlgren's survey, resulting in complex and heterogeneous grouping. Taxonomic revision based on newly collected material and the re-description of the type of material quite often can help reduce the change of species between taxa. One example is the revision of the family Kadosactidae Riemann-Zürneck, 1991. Riemann-Zürneck (1991: 191204) established this family after re-describing newly sampled material of Kadosactis sulcata Carlgren, 1934, and revising the species included in Kadosactis Danielssen, 1890. According to her revision, the monogeneric family Kadosactidae includes three species: $K$. rosea Danielssen, 1890, K. sulcata and K. antarctica (Carlgren, 1928). This family was characterized among the $\mathrm{Ny}$ nantheae with acontia by an archaic nematocyst configuration: large " $p$-rhabdoids B" in all tissues, no " $p$ rhabdoids A" (sensu Schmidt 1969) and large "hormathiid" spirocysts.

Eleven specimens identified as the deep-sea anemone Sagartiogeton antarcticus Carlgren, 1928 were collected during the $\mathrm{R} / \mathrm{V}$ Polarstern ANDEEP-I cruise to the Scotia Sea and off the South Shetland Islands (Antarctica). This species was previously only known from its original description (Carlgren 1928: 231-233). It had been transferred from Sagartiogeton Carlgren, 1924 (Carlgren 1928: 231-233; 1949: 106) to Kadosactis (Carlgren 1942: 9; Riemann-Zürneck 1991), but neither the type nor additional material of Kadosactis antarctica have ever been re-examined, except for a label placed by D. Fautin in 1996 indicating that the holotype had dried 
up (Fautin 2004). The study of the newly collected material and the type material has offered new data about specific and generic characteristics of the species, and also extended its geographic and bathymetric distribution.

\section{Materials and methods}

The studied material was collected on the R/V Polarstern cruise ANT XIX/3 (ANDEEP-I), sponsored by the Alfred-Wegener-Institut für Polar-und Meeresforschung in Bremerhaven, during the austral summer of 2002 to the Scotia Arc, Antarctica. The material studied in the present work was sampled off the South Shetland Islands (Fig. 1).

Sea anemones were relaxed on board using menthol crystals and subsequently fixed in $10 \%$ seawater formalin. Fragments of three specimens were dehydrated in butanol (Johansen 1940), and embedded in paraffin. Histological sections 7-8 $\mu \mathrm{m}$ thick were stained with Ramón y Cajal's Triple Stain (Gabe 1968).

Squash preparations of cnidae from the preserved material were measured at $1000 \mathrm{X}$ magnification with Nomarski differential interference contrast optics. The nomenclature used for the cnidae is from Mariscal (1974) and Östman (2000), with modifications: the nomenclature for basitrichs and $b$-mastigophores is from Carlgren (1940) and Mariscal (1974), due to the obscure distinction between these categories (see Östman 2000: 42). Frequencies given are subjective impressions based on squash preparations. Mean and standard deviation of the size ranges of cnidae measurements are provided. Presence of each type of cnidae in each tissue has been confirmed in the histological sections of the tissues.

The newly collected material has been deposited in the Zoologisches Institut und Zoologisches Museum in
Hamburg (ZMH), the National Museum of Natural History, Smithsonian Institution in Washington (USMN), and the collection of research team "Biodiversidad y Ecología de Invertebrados Marinos" at the University of Seville in Spain (BEIM).

For the purpose of comparison, the following material deposited at the Museum für Naturkunde in Berlin (ZMB) was examined:

Sagartiogeton antarcticus, Carlgren, 1928. (ZMB Cni 8441). Typus: Carlgren determ. Leg: 1898-99, Deutsche Tiefsee-Exp., St 152, 63ำ $16.5^{\prime} \mathrm{S} 57^{\circ} 51^{\prime} \mathrm{E}, 4636 \mathrm{~m}$ depth.

Remarks: This material was examined by Daphne G. Fautin twice (in 1996 and 2001). She included an additional label: "had dried 1996".

\section{Results}

Order Actiniaria Hertwig, 1882

Suborder Nynantheae Carlgren, 1899

Family Kadosactidae Riemann-Zürneck, 1991

Genus Kadosactis Danielssen, 1890

Diagnosis (from Carlgren 1949: 105 and after Riemann-Zürneck 1991; amended according to the redescriptions of the three species currently included in the genus; changes italicized): Nynantheae with basilar muscles present. Body with well-developed base. Column divisible into scapus and scapulus, the former usually with a cuticle, usually deciduous, and with tenaculi(?). Column with cinclides formed by ectoderm as well as by endoderm and situated between scapus and scapulus. Margin more or less distinct. Sphincter strong, mesogloeal. Tentacles of variable length, conical, hexamerously arranged. Outer tentacles thickened on the aboral side of their bases. Same number of tentacles and mesenteries, up to 48. Longitudinal muscles of tentacles and radial muscles of oral disc ectodermal. Two si-

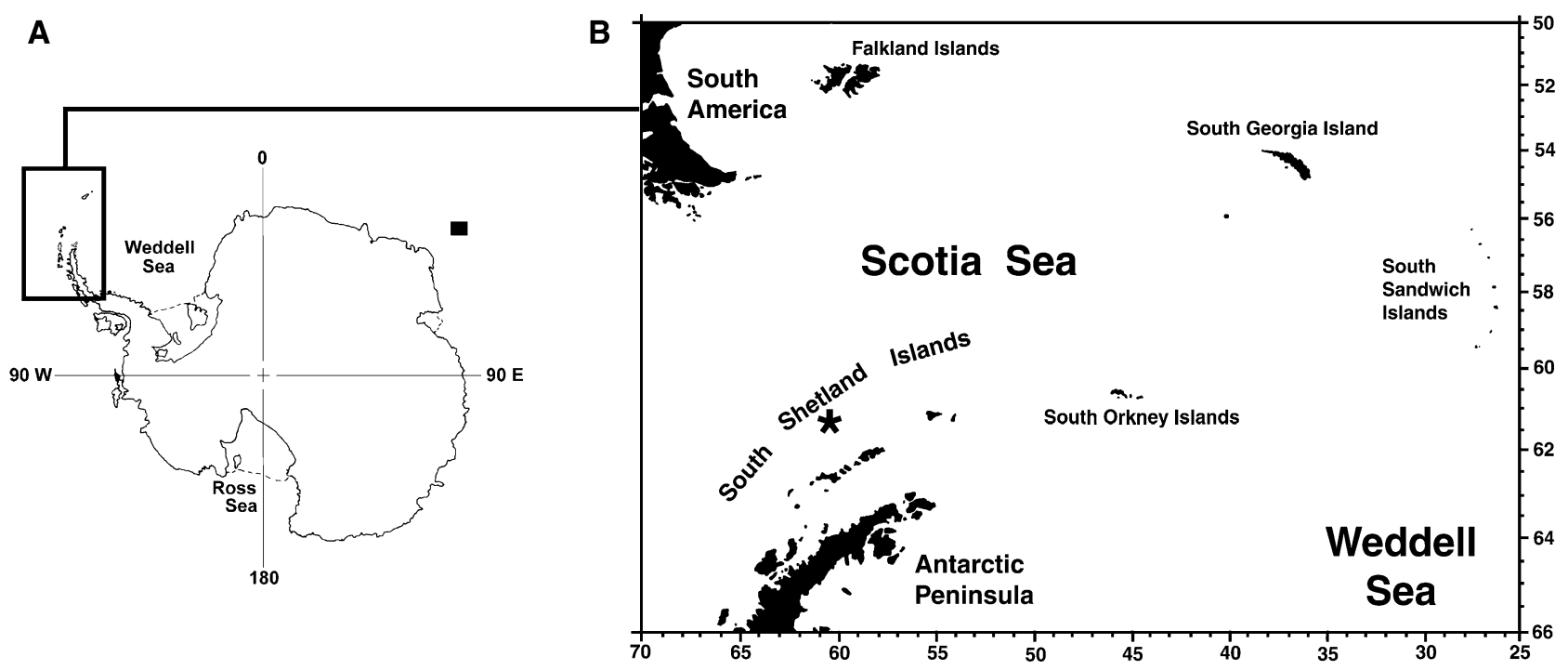

Fig. 1 Known distribution of $K$. antarctica (Carlgren, 1928). a Type locality ( $\square)$. b New records from ANDEEP cruise (*) 
Fig. 2 External anatomy of $K$. antarctica (Carlgren, 1928). a Living and relaxed specimen, lateral view. b-d Preserved specimens. b ZMH (C11690) in lateral view; note the annulus of cinclides at the borderline between the scapus and the scapulus. c Lateral view (ZMH C11690) showing the aboral end. d Oral view (ZMH C11690). $c i$ cinclides, $r c$ remains of cuticle, $s c$ scapus, $s l$ scapulus. Scale bar: a-d $30 \mathrm{~mm}$
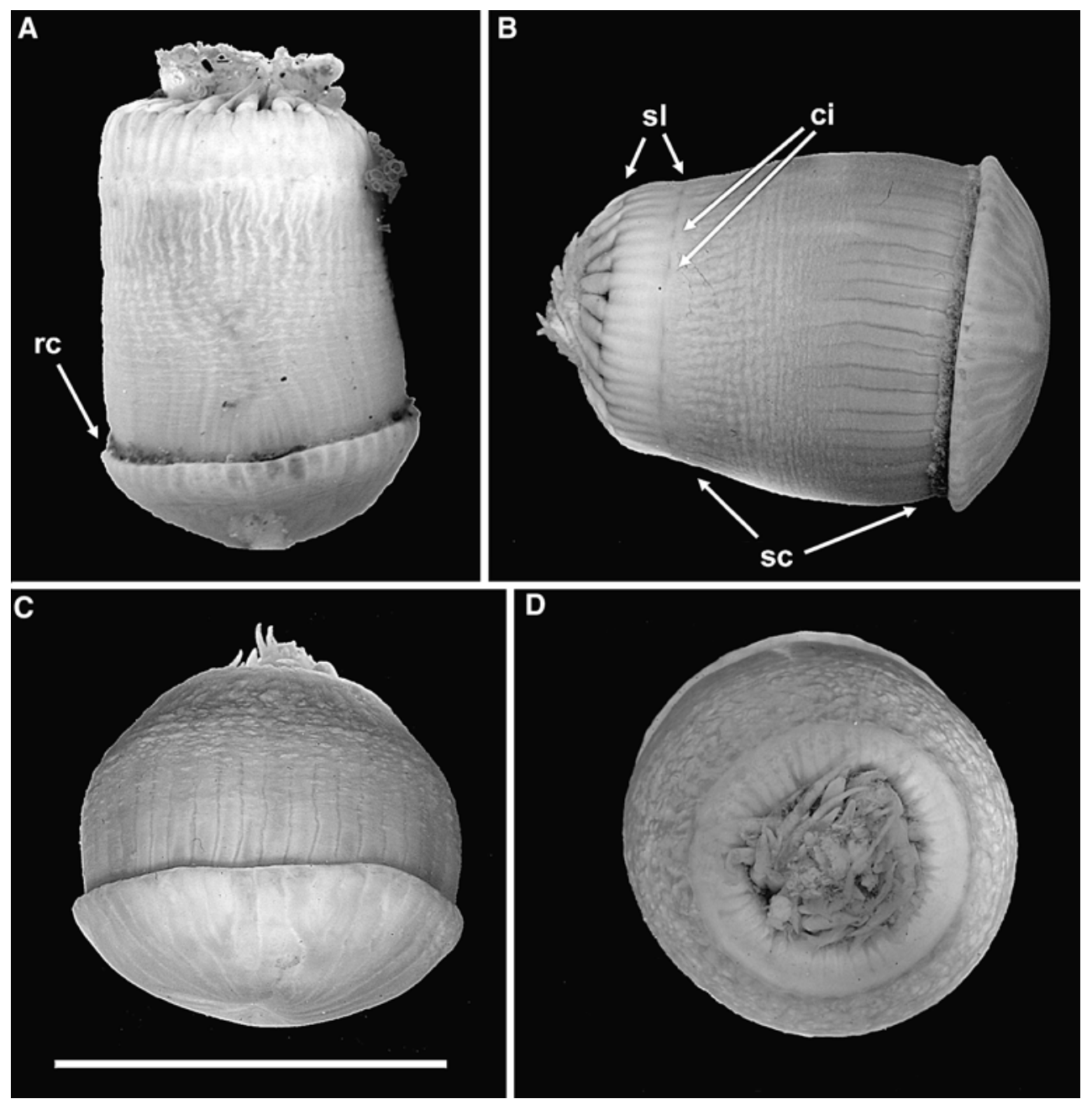

phonoglyphs, two pairs of directives. Arrangement of mesenteries hexamerous. Twelve pairs of perfect mesenteries. Perfect mesenteries and sometimes the stronger imperfect ones with strong diffuse retractors, which are extended over the whole surface. Parietobasilar muscles not strong. The stronger mesenteries, including the directives, fertile. Acontia poorly developed. Cnidom: spirocysts, basitrichs, and microbasic $p$-mastigophores (p-rhabdoids B).

Nominal species: Kadosactis rosea Danielssen, 1890 (type species); K. antarctica (Carlgren, 1928); K. sulcata Carlgren, 1934

Kadosactis antarctica (Carlgren, 1928; Figs. 1-6, Table 1)

Sagartiogeton antarcticus Carlgren, 1928: 231-233 (109-111), Taf. II, Fig. 2; Carlgren 1949: 106

Kadosactis antarctica Carlgren, 1942: 9; RiemannZürneck 1991: 191-204.

Material: ZMH (C11690), four specimens, Polarstern ANT XIX/3, stn. PS61/114-10, Scotia Sea, 61 $43.70^{\prime}$ S $60^{\circ} 42.62^{\prime} \mathrm{W}, 2852.9-2856.2 \mathrm{~m}$ depth, 19 Feb 2002, Agassiz trawl; BEIM (ANT-4075), four specimens; BEIM (ANT-4037), one specimen; USMN (1078161), two specimens. Sg data same for all lots of material.
Diagnosis: Firm, cylindrical body with well-developed pedal disc. Column divisible into scapus and scapulus, the former with easily deciduous cuticle. Borderline between scapus and scapulus marked with annulus of 22 cinclides. Same number of mesenteries and tentacles (48). Mesenteries arranged in three cycles: first and second cycle, perfect and fertile, and third, imperfect and sterile. Retractor musculature diffuse. Parietobasilar and basilar musculature weak, poorly developed. Sphincter muscle mesogloeal, strong and reticular. Cnidom: Spirocysts, basitrichs, and microbasic $p$-mastigophores ( $p$ rhabdoids B).

Description: External anatomy (Figs. 2, 3): Body firm, cylindrical to globular, about $30 \mathrm{~mm}$ diameter and $39 \mathrm{~mm}$ height in preserved specimens (Fig. 2a, c). Aboral end well developed, about $31 \mathrm{~mm}$ diameter, conical in most specimens with mesenteric insertions visible (Fig. 2c). No cuticle observed on pedal disc. Column divisible into scapus and scapulus (Fig. 2b). Scapus with stratified cuticle that is almost totally eroded in all specimens. Mesenteric insertions visible in the most proximal part of scapus. Distal part of scapus with minute mesogloeal papillae whose true nature is hard to define because of the condition of specimens. Annulus of 

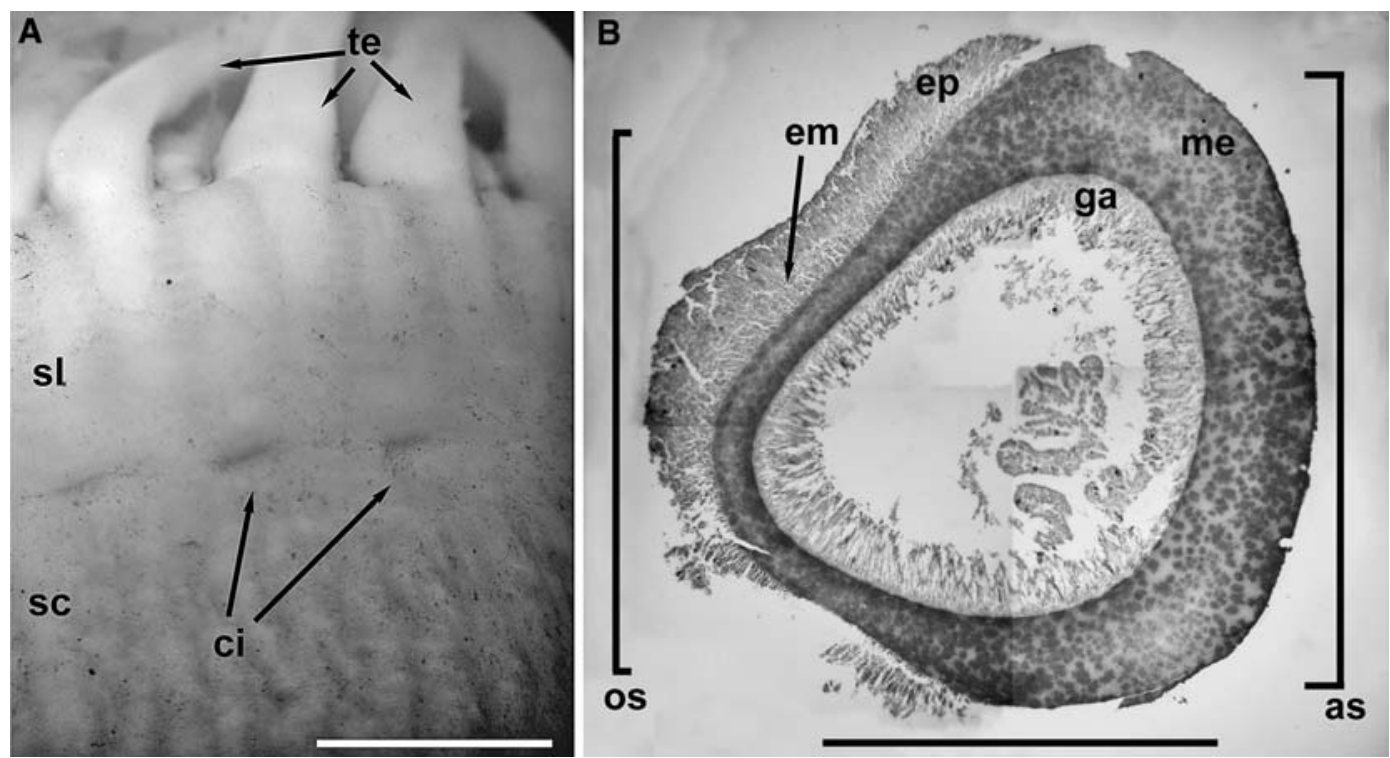

Fig. 3 K. antarctica (Carlgren, 1928). a Detail of the cinclides at the borderline between scapus and scapulus. b Cross-section of the basal part of an outer tentacle showing the mesogloeal thickening of the aboral side. as aboral side, $c i$ cinclides, em ectodermal longitudinal musculature, ep epidermis, ga gastrodermis, me mesogloea, os oral side, sc scapus, sl scapulus, te tentacles. Scale bar: a $5 \mathrm{~mm}$, b $1 \mathrm{~mm}$

22 cinclides, corresponding with endocoels, encircle borderline between scapus and scapulus (Fig. 3a). Scapulus smooth, $6 \mathrm{~mm}$.

Oral disc slightly smaller in diameter $(29 \mathrm{~mm})$ than pedal disc in preserved specimens. Tentacles not retracted in most preserved specimens, stout, conical, shorter than the diameter of oral disc. Inner tentacles more or less equal in length (about $12 \mathrm{~mm}$ ) to outer ones, about 48 in number, appear-in the preserved state - to be arranged in two cycles, an inner and an outer one. Tentacles thickened on aboral surface; mesogloeal thickenings just visible in histological sections (Fig. 3b)

Internal anatomy (Figs. 4, 5): equal number of mesenteries both distally and proximally. Mesenteries hexamerously arranged in three cycles: first and second cycle, perfect and fertile; third cycle, imperfect and sterile (Fig. 4a). Two pairs of fertile directives, connected with two strong, thickened and well-developed siphonoglyphs (Fig. 4a). Mesogloea and gastrodermis of siphonoglyph wider than mesogloea and gastrodermis of actinopharynx. Retractor musculature diffuse (Fig. 4c). Parietobasilar musculature weak, poorly differentiated (Fig. 4b). Basilar musculature poorly developed (Fig. 4d). Acontia difficult to discern in dissection but visible in histological section (Fig. 4e). Gametogenic tissue well developed in specimens collected in February; gonochoric; developing oocytes to $0.2 \mathrm{~mm}$ in diameter in the histological sections of preserved specimens.

Sphincter muscle mesogloeal, strong and reticular, restricted to scapulus and occupying its entire length (Fig. 5a). Tentacles and oral disc with ectodermal longitudinal musculature (Fig. 5d). Column wall of similar thickness on entire length; epidermis $0.13-0.23 \mathrm{~mm}$; mesogloea $0.35-0.40 \mathrm{~mm}$ thick, and gastrodermis 0.17 $0.35 \mathrm{~mm}$ thick. Cuticle 3-6 $\mu \mathrm{m}$ thick.

Cnidom (Fig. 6): spirocysts, basitrichs, and microbasic $p$-mastigophores ( $p$-rhabdoids B). A survey of the cnidae is presented in Table 1 and Fig. 6.

Colour: living material with whitish tentacles and pale salmon-coloured scapulus, actinopharynx and mesenteric filaments; scapus similar in colour to scapulus distally where it lacks cuticle, brownish proximally because of cuticle. Preserved material pink coloured.

Geographic and depth distribution: Kadosactis antarctica was previously known only from its type of locality, inhabiting abyssal waters (4636 m depth) off Kemp Coast $\left(63^{\circ} 16.5^{\prime} \mathrm{S} 57^{\circ} 51^{\prime} \mathrm{E}\right)$ (see Fig. 1). This contribution extends the geographic and depth distributions of $K$. antarctica to the south branch of the Scotia Sea $\left(61^{\circ}\right.$ $43.70^{\prime} \mathrm{S} 60^{\circ} 42.62^{\prime} \mathrm{W}$ ), and bathyal waters from 2852.9 to 2856.2 m depth. Riemann-Zürneck (1991: 200) misunderstood the longitude of the type of locality of Sagartiogeton antarcticus and cited it (as K. antarctica) in the South Shetland Trench.

\section{Discussion}

Differential diagnosis of the species of the genus Kadosactis Danielssen, 1890: K. antarctica corresponds in most aspects of its general morphological structure and sizes ranges and distribution of cnidae to the other two members of the genus, $K$. rosea and $K$. sulcata. These three species are distinguished only by slight differences as the following differential diagnosis shows:

Kadosactis rosea Danielssen, 1890: Kadosactis with inverted cone-shaped column, $22 \mathrm{~mm}$ height. Scapus 

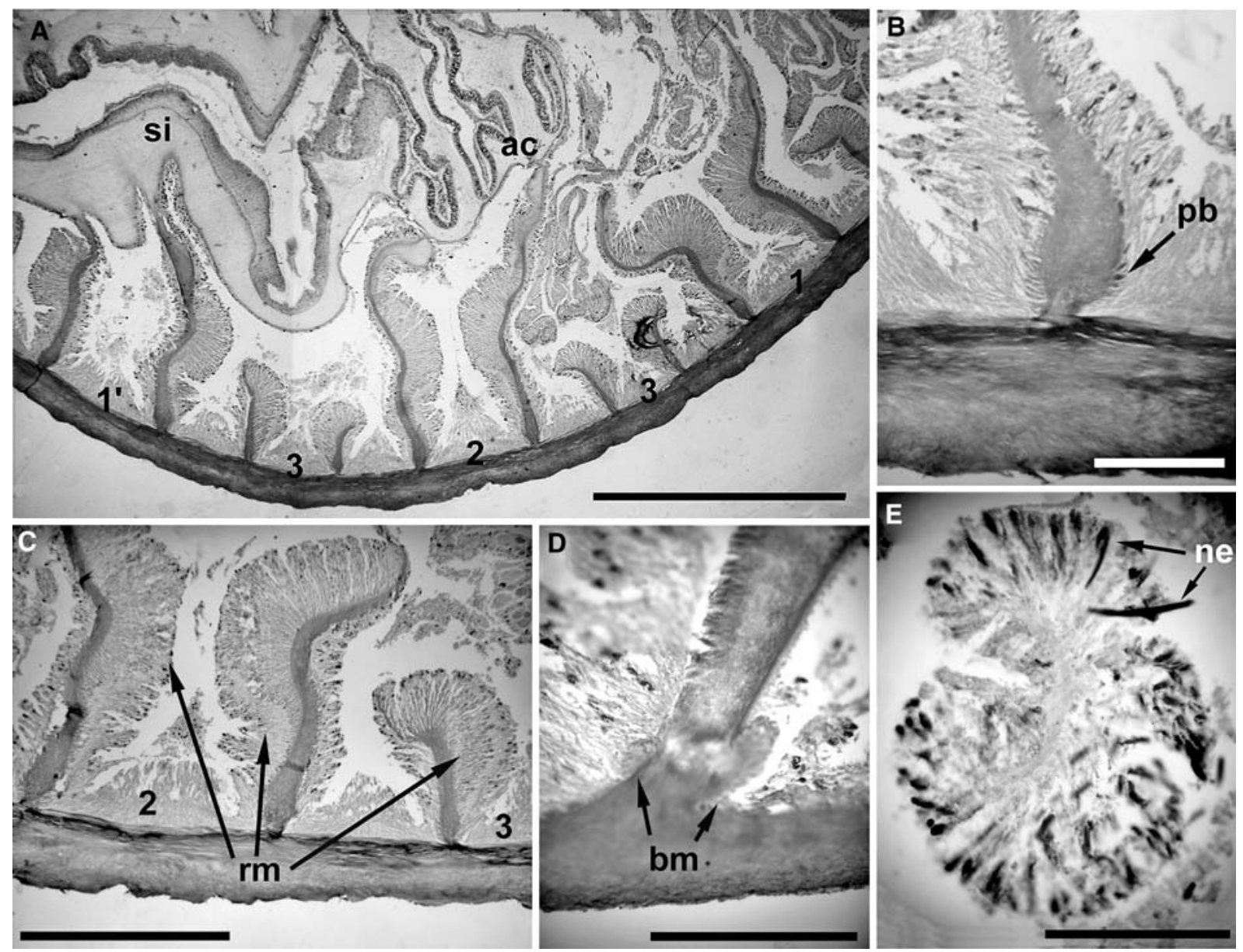

Fig. 4 Internal anatomy of $K$. antarctica (Carlgren, 1928). a Cross-section at actinopharynx level. b Detail of a mesentery showing the weak parietobasilar musculature. $\mathbf{c}$ Detail of the retractor musculature of mesenteries from the second and the third cycle. $\mathbf{d}$ Longitudinal section through the proximal part of the mesenteries showing the basilar musculature. e Acontium in cross-section; note the nematocyst on the tissue. $l^{\prime}$ directive pair of mesenteries, 1 pair of mesenteries of the first cycle, 2 pair of mesenteries of the second cycle, 3 pair of mesenteries of the third cycle, $a c$ actinopharynx, $b m$ basilar musculature, ne nematocyst, $p b$ parietobasilar musculature, $r m$ retractor musculature, si siphonoglyph. Scale bars: a $2.5 \mathrm{~mm}$, b $250 \mu \mathrm{m}$, c $1 \mathrm{~mm}$, d $250 \mu \mathrm{m}$, e $200 \mu \mathrm{m}$

with a deciduous cuticle and weak tenaculi. Number of tentacles, 44. No microbasic $p$-mastigophores in the tentacles. Arctic deep-sea species.

Kadosactis antartica Carlgren, 1928: Kadosactis with cylindrical to globular column, $39 \mathrm{~mm}$ height. Scapus smooth but with small mesogloeal papillae and remains of deciduous cuticle. Number of tentacles, 48. Antarctic deep-sea species.

K. sulcata Carlgren, 1934: Kadosactis with globular column, $35 \mathrm{~mm}$ in height. Scapus faintly tuberculate and without cuticle(?). Number of tentacles, 40. North Atlantic deep-sea species.

Differences in shape and size of the column are often due to the state of relaxation and the process of fixation. The structure of the column is not really clear in the three species of Kadosactis due to the limited number of specimens available and their poor condition. The presence of cuticle is usually a generic character; the absence of cuticle in one of the species, even more in such a homogenous genus, seems strange. Therefore, we think that the absence of cuticle in the scapus of
K. sulcata is probably due to the state of the material. The variability and boundaries of these characters have to be checked and their occurrence in isolation cannot be seen as specific characters until then.

The cnidae is very homogenous in the three species of Kadosactis; the size ranges of the capsules are very similar, overlapping in the three species (see RiemmanZürneck 1991: 195-196 and 200-201 and Table 1). The absence of microbasic $p$-mastigophores in the tentacles of $K$. rosea can probably be accounted for by the fact that just one specimen was used for compiling the cnidae data (Riemman-Zürneck 1991: 199) and to their low frequency, although this is based on subjective impressions of this type of cnida in the other species (we have found only 19 capsules in five measured specimens).

The morphological diagnostic characters used until now do not provide enough evidence to separate clearly the three species of Kadosactis. The minor differences in the shape, structure and size of the column, and the worldwide distribution of the three species might render Kadosactis, a very homogeneous genus. The variability 


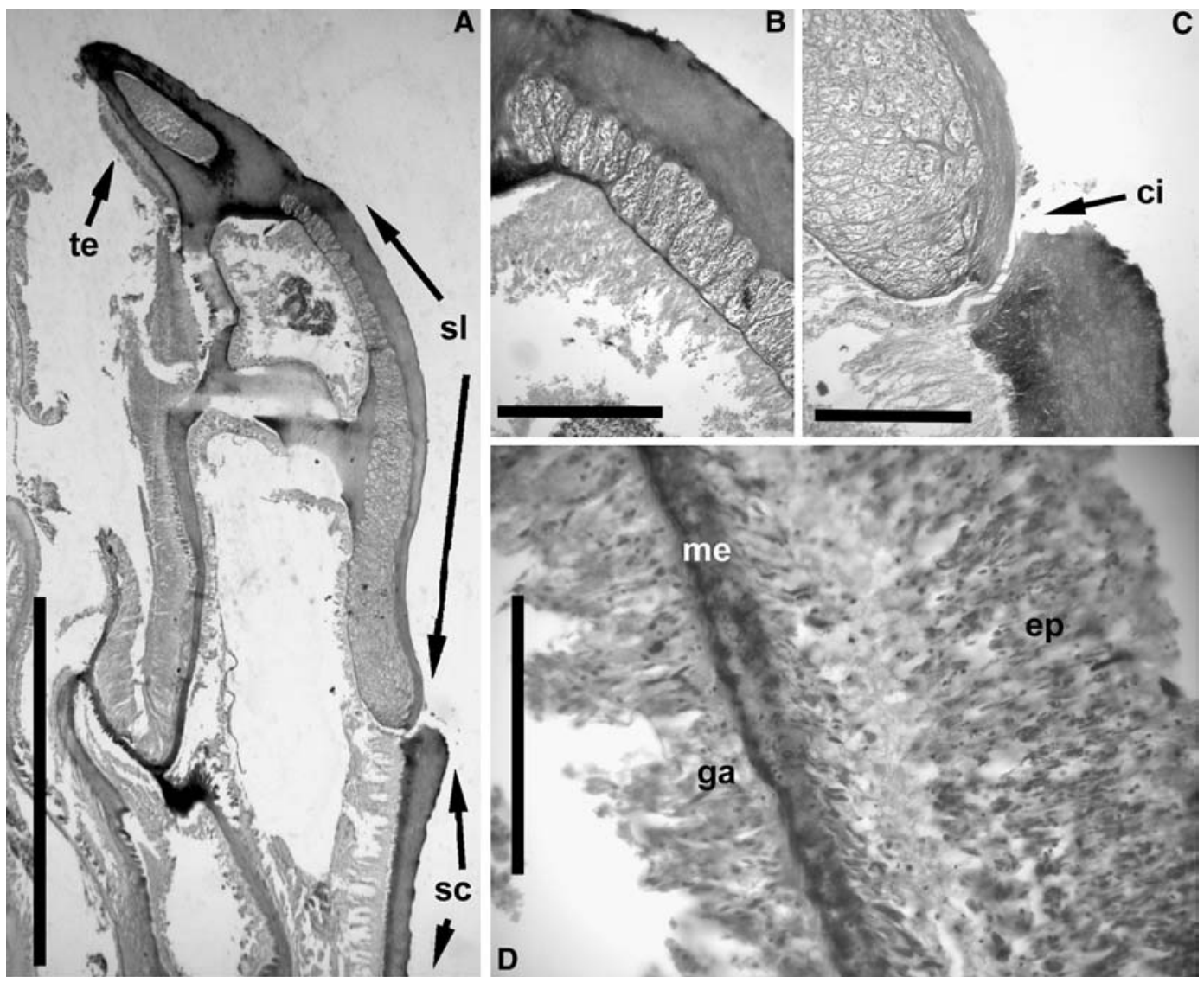

Fig. 5 K. antarctica (Carlgren, 1928). a Mesogloeal sphincter in longitudinal section. b Detail of the distal part of the sphincter; note the reticular appearance of the mesogloeal lacunae. $\mathbf{c}$ Detail of the proximal part of the sphincter showing a cinclide at the borderline between the scapus and the scapulus; note the appearance of the mesogloeal lacunae d Ectodermal longitudinal musculature of the tentacles. $c i$ cinclide, $e p$ epidermis, $g a$ gastrodermis, me mesogloea, $s c$ scapus, $s l$ scapulus, te tentacle. Scale bars: a $2.5 \mathrm{~mm}, \mathbf{b}-\mathbf{c} 300 \mu \mathrm{m}, \mathbf{d} 125 \mu \mathrm{m}$

of the traditional diagnostic characters is not enough to discard the possibility of Kadosactis being a widely distributed deep-sea species. The slight differences in the three species might be interpreted then as different populations of one species. Such a wide distribution would be justified by the connection across the deep-sea bottoms.

However, until more material is available for further and more clarifying studies, we prefer to maintain $\mathrm{Ka}$ dosactis as a genus with three species, K. rosea, K. sulcata and $K$. antarctica, instead of promoting the idea of a species complex in this genus.

Background of the generic placement of Sagartiogeton antarcticus Carlgren, 1928: Carlgren (1924: 26) erected the genus Sagartiogeton for the species $S$. robustus Carlgren, 1924. At that time, Sagartiogeton was differentiated from Kadosactis by the presence of tenaculi, cinclides, tentacles without thickenings on their aboral side, and acontia with two kinds of nematocysts in $\mathrm{Sa}$ gartiogeton. Later, Carlgren (1928: 231) described a second species of Sagartiogeton, S. antarcticus, from a single specimen from deep Antarctic waters. In subsequent works, Carlgren (1932: 264; 1933: 21) first distinguished and then synonymized the genera Kadosactis and Sargartiogeton. His observations were made from badly preserved material of $K$. rosea, and he confused the cnidom of the acontia and overlooked an annulus of small cinclides on the lower part of the scapulus of $K$. rosea. The cnidae of $K$. rosea was re-examined and illustrated by Riemann-Zürneck (1991: 200-201), clarifying this confusion.

Having taken into account other diagnostic characters, Carlgren (1942: 9) changed opinion, finally differentiating Kadosactis and Sagartiogeton. He gave a diagnosis of the genus Kadosactis and detailed descriptions of most of its species, including $K$. abyssicola (Koren and Danielssen, 1877), K. (Sagartiogeton) antarctica, K. spitsbergensis (Danielssen, 1890) and $K$. (Sagartiogeton) sulcata. Carlgren also gave the diagnosis and description of the genus and species of $\mathrm{Sa}$ gartiogeton. He stated then that in Sagartiogeton, mesenteries grow proximally as well as distally but originate earlier proximally (the mesenteries are therefore more numerous proximally). For Kadosactis, he stated that the mesenteries grow proximally towards distally (so there are more mesenteries proximally than distally).

However, Carlgren (1949: 101) later listed K. antarctica under the genus Sagartiogeton again. He partly distinguished Sagartiogeton and Kadosactis by the 


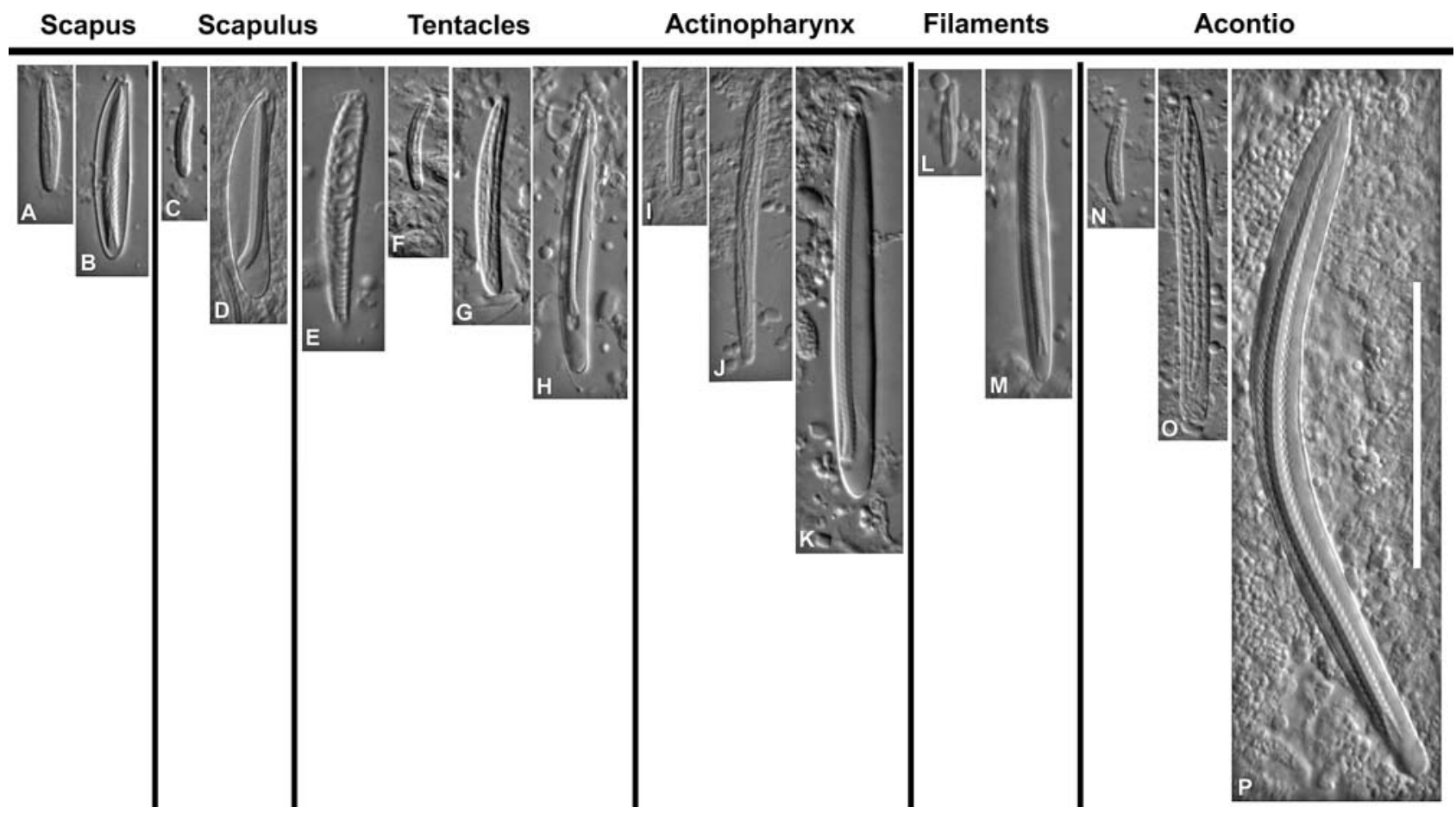

Fig. 6 Cnidae of $K$. antarctica (Carlgren, 1928). a Basitrich 1. b Microbasic $p$-mastigophore. c Basitrich 1. d Microbasic $p$-mastigophore. e Spirocyst. f Basitrich 1. g Basitrich 2. h Microbasic $p$-mastigophore. i Basitrich 1. j Basitrich 2. k Microbasic p-mastigophore. I Basitrich 1. m Microbasic $p$-mastigophore. n Basitrich 1. o Basitrich 2. p Microbasic p-mastigophore. Scale bar: $50 \mu \mathrm{m}$

number of mesenteries proximally and distally, and contradicted his earlier paper, stating that in Sagartiogeton the mesenteries grow simultaneously proximally and distally but originated earlier distally than proximally (Carlgren 1949: 105). In most of the well-known species of the genus Sagartiogeton, mesenteries originate earlier distally (Manuel 1988; López-González 1993, unpublished). Unfortunately, doubts about this character cannot be verified in the type material of $K$. antarctica due to the lack of information about the number of proximal and distal mesenteries in the original description of Carlgren (1928: 231-233) and also because of the current state of the only type specimen. The revision of the genus Kadosactis by Riemann-Zürneck (1991) does not help in this matter either, because she does not mention this character in either the descriptions or in the diagnosis of the species that she studied. The newly collected material of $K$. antarctica we examined has the same number of mesenteries proximally and distally. Nevertheless, until a revision of this character in the other species of Kadosactis is performed, we prefer not to include the number of mesenteries proximally and distally in the diagnosis of the genus.

One difference between Kadosactis and Sagartiogeton is that in Kadosactis, the mesogloea of the tentacles is thickened on the aboral side of the base, whereas in Sagartiogeton, this mesogloea is never thickened. Carlgren (1928) originally described $K$. antarctica as not having tentacles thickened on the aboral sides of their bases. Riemann-Zürneck (1991: 200) used this character as a specific difference between $K$. antarctica and $K$. sulcata (absent and present, respectively). However, in the newly collected specimens of $K$. antarctica, we have found that the tentacles are thickened on the aboral side of their bases (Fig. 3b). Carlgren (1942: 9; 1949: 105) probably did not observe these basal mesogloeal thickenings because they are only recognizable under histological sections, and this is probably also the reason why he listed $K$. antarctica under Sagartiogeton again in 1949. Thus, as the three species within Kadosactis have mesogloeal aboral basal thickenings in the tentacles, we consider it a generic character for Kadosactis and therefore we included it in the diagnosis of the genus.

The differentiation of macronemes and micronemes is one character traditionally used to distinguish higher taxonomic levels in Actiniaria. Despite its unquestionable value for characterizing some taxa, several studies have revealed a few acontiarian taxa with intermediate states of this character (Stephenson 1920: 458-459; Pinto pers. comm., and pers. obser.). Therefore it has to be used carefully and should be re-evaluated in each particular case. Riemann-Zürneck (1991: 202) described the mesenteries for Kadosactis species as differentiable into macronemes and micronemes but does not provide pictures of them. In accordance with Stephenson (1920: 456), we neither consider the difference between the cycles of mesenteries in our material as macronemes and micronemes (Fig. 4), nor do we see this distinction in the holotype of $K$. antarctica (see Carlgren 1928: 232 Texfig. 
Table 1 Summary of size ranges of the cnidae of $K$. antarctica (Carlgren, 1928)

\begin{tabular}{|c|c|c|c|c|c|c|c|}
\hline Category & Figure & $\begin{array}{l}\text { Range of length and } \\
\text { width of capsules }(\mu \mathrm{m})\end{array}$ & $\mathrm{X} \pm \mathrm{SD}$ & Sample & $\mathrm{N}$ & $\mathrm{F}$ & $\begin{array}{l}\text { Data from Carlgren } \\
(1928)^{\mathrm{a}}\end{array}$ \\
\hline \multicolumn{8}{|l|}{ SCAPUS } \\
\hline Basitrichs 1 & A & $(14.1-25.2) \times(3.0-4.0)$ & $19.8 \pm 2.6 \times 3.6 \pm 0.5$ & $3 / 3$ & 62 & $++/+++$ & $(12-19) \times 1.5$ \\
\hline $\begin{array}{l}\text { M. p-mastigophores } \\
\text { SCAPULUS }\end{array}$ & B & $(26.3-41.4) \times(5.0-6.1)$ & $33.0 \pm 4.3 \times 5.7 \pm 0.5$ & $3 / 3$ & 52 & $++/+++$ & $(29-50) \times(4-5)$ \\
\hline Basitrichs 1 & $\mathrm{C}$ & $(12.1-22.2) \times(3.0-4.0)$ & $16.2 \pm 2.8 \times 3.1 \pm 0.4$ & $3 / 3$ & 51 & $+/++$ & No data \\
\hline $\begin{array}{l}\text { M. } p \text {-mastigophores } \\
\text { TENTACLES }\end{array}$ & $\mathrm{D}$ & $(31.3-46.5) \times(6.1-9.1)$ & $36.3 \pm 3.1 \times 7.0 \pm 0.8$ & $2 / 3$ & 40 & $+/++$ & No data \\
\hline Spirocysts & $\mathrm{E}$ & $(25.2-60.6) \times(4.0-9.1)$ & $42.3 \pm 8.2 \times 6.0 \pm 1.4$ & $5 / 5$ & 65 & $-/+++$ & $(24-60) \times(2.5-6.5)$ \\
\hline Basitrichs 1 & $\mathrm{~F}$ & $(15.2-23.2) \times(2.0-4.0)$ & $17.6 \pm 1.6 \times 3.1 \pm 0.3$ & $5 / 5$ & 62 & ++ & \\
\hline Basitrichs 2 & $\mathrm{G}$ & $(24.1-36.4) \times(3.0-4.0)$ & $30.5 \pm 2.9 \times 3.5 \pm 0.5$ & $5 / 5$ & 73 & ++ & $(31-38) \times 3$ \\
\hline $\begin{array}{l}\text { M. p-mastigophores } \\
\text { ACTINOPHARYNX }\end{array}$ & $\mathrm{H}$ & $(33.0-65.7) \times(5.0-8.1)$ & $47.6 \pm 10.6 \times 5.9 \pm 0.9^{*}$ & $5 / 5$ & 19 & $-1+$ & $(50-55) \times 5$ \\
\hline Basitrichs 1 & I & $(14.1-24.2) \times(2.0-3.0)$ & $16.4 \pm 2.3 \times 3.0 \pm 0.4$ & $3 / 3$ & 50 & $++/+++$ & $(14-17) \times 1.5$ \\
\hline Basitrichs 2 & $\mathbf{J}$ & $(40.4-57.6) \times(4.0-5.0)$ & $50.8 \pm 5.0 \times 4.1 \pm 0.3$ & $3 / 3$ & 51 & $+/++$ & \\
\hline $\begin{array}{l}\text { M. p-mastigophores } \\
\text { FILAMENTS }\end{array}$ & $\mathrm{K}$ & $(51.5-69.7) \times(6.1-7.1)$ & $62.2 \pm 4.1 \times 6.9 \pm 0.6$ & $3 / 3$ & 59 & ++ & $(50-60) \times(4.5-5)$ \\
\hline Basitrichs 1 & $\mathrm{~L}$ & $(12.1-30.0) \times(2.0-4.0)$ & $16.2 \pm 4.1 \times 2.9 \pm 0.6$ & $5 / 5$ & 70 & $+/++$ & No data \\
\hline $\begin{array}{l}\text { M. p-mastigophores } \\
\text { ACONTIA }\end{array}$ & M & $(36.4-56.6) \times(4.0-7.1)$ & $42.8 \pm 2.3 \times 5.2 \pm 0.6$ & $5 / 5$ & 73 & +++ & No data \\
\hline Basitrichs 1 & $\mathrm{~N}$ & $(12.1-26.3) \times(2.0-3.0)$ & $15.9 \pm 2.4 \times 3.1 \pm 0.2$ & $2 / 2$ & 50 & $-1+++$ & \\
\hline Basitrichs 2 & $\mathrm{O}$ & $(39.4-65.7) \times(5.0-6.1)$ & $57.9 \pm 5.1 \times 5.5 \pm 0.5$ & $2 / 2$ & 55 & $++/+++$ & $(48-65) \times(3.5-4)$ \\
\hline M. $p$-mastigophores & $\mathrm{P}$ & $(104.0-136.4) \times(8.1-12.1)$ & $120.8 \pm 7.2 \times 9.7 \pm 0.9$ & $2 / 2$ & 55 & +++ & $(98-115) \times(6-6.5)$ \\
\hline
\end{tabular}

${ }^{a}$ Categories of the nematocysts were not specified in Carlgren (1928). X average, $S D$ standard deviation, Samples the ratio indicates the number of specimens in which each cnidae was found out compared to the number of specimens examined, $N$ indicates the total number of capsules measured, $F$ frequency, +++ very common, ++ common, + rather common, - sporadic. Abbreviation: $M$ Microbasic. *Average based on less than 40 measured capsules, the measurement of at least 40 capsules is usually considered enough to have significance. Some discharged capsules of microbasic $p$-mastigophores (size ranges $(50-67) \times(6-7)$ in $5 / 5$ specimens) have also been found

65). Therefore, we do not include this character in the diagnosis of the species or in the diagnosis of the genus.

Familial placement of the genus Kadosactis Danielssen, 1890: The genus Kadosactis was at first placed in the family Paractidae Hertwig, 1882 (see Danielssen 1890: 8). However, Haddon (1898: 301) briefly reviewed and redefined the family Sagartiidae (Gosse, 1858), and included Kadosactis within it. Carlgren (1949: 86) redefined the family Sagartiidae as Thenaria (Acontiaria) with mesogloeal sphincter, usually strong, with mesenteries not divisible into macronemes and micronemes, and typical acontia with numerous nematocyst, basitrichs and microbasic amastigophores (microbasic $p$ amastigophores, sensu Östman 2000).

Riemann-Zürneck (1991) revised the genus Kadosactis and established the family Kadosactidae based upon the archaic nematocyst endowment of the family: large " $p$-rhabdoids B" and no " $p$-rhabdoids A" (sensu Schmidt 1969). She argued that the diagnosis of the genus is inconsistent with its position within the family Sagartiidae, wherein the archaic cnidom is considered to be of highest priority (Hand 1955: 190). Some discharged microbasic $p$-mastigophores have been observed in the acontia of the material of $K$. antarctica studied here; these have a distal tubule in the discharged capsules and are thus microbasic $p$-mastigophores rather than microbasic $p$-amastigophores). Thus, the newly collected specimens of $K$. antarctica (which have microbasic $p$-mastigophores rather than microbasic $p$ amastigophores in the acontia) support the exclusion of
Kadosactis from Sagartiidae and support the creation of Kadosactidae.

Currently, the determination of useful characters and their polarity within the different actiniarian families for a natural classification of the order is extremely complex. Therefore, both the position of the family Kadosactidae and the tentative grouping of the mesomyarian sea anemones into "early" and "late" mesomyarians (Schmidt 1972; 1974) awaits a more comprehensive study of the natural classification of the order Actiniaria, an aspect beyond the aim of this contribution.

Acknowledgements Special thanks are addressed to Dr. JosepMaria Gili (Institut de Ciències del Mar-CMIMA, Barcelona) and Prof. Wolf Arntz (Alfred-Wegener-Institute, Bremerhaven) who made our cooperation and participation in several Antarctic cruises possible. We also thank Prof. Dr. Dieter K. Fütterer, coordinator and scientific chief of the ANDEEP-I cruise, and Dr. A. Brandt (Institut Zoology, University Hamburg), member of the steering committee of the ANDEEP Project.Thanks also to $M$. Conradi (BEIM, University of Seville), who collected and photographed the material studied in this manuscript. Friendly comments from and discussions with Vreni Häussermann and S. Pinto Machado helped a lot in the development of this manuscript. Comments from an anonymous referee have clarified the manuscript substantially. Dr. Carsten Lueter (Museum für Naturkunde in Berlin (ZMB)) kindly provided the loan of the type of material of $S$. antarcticus. The authors also acknowledge the helpful assistance of the Department of Cellular Biology of the University of Seville for the use of histological equipment. We extend our acknowledgements to the officers and crew of the $\mathrm{R} / \mathrm{V}$ Polarstern, and many colleagues on board during the ANDEEP-I cruise for their valuable assistance. Melanie and Philip Moell and M. Daly are thanked for reviewing the English. Support was provided by a MCT-CSIC grant (I3P- 
BPD2001-1) to E. Rodríguez and Spanish CICYT projects: ANT97-1533-E, ANT98-1739-E, ANT99-1608-E, and REN20014269-E/ANT. This is publication number 50 of ANDEEP Project.

\section{References}

Carlgren O, (1899) Über abschnürbare tentakel bei den actiniarien Zool Anz 578(22):39-44

Carlgren O, (1924) Description de deux Actiniaria Bull Inst Ocean. Monaco 438:26-28

Carlgren O, (1928) Actiniaria der deutschen tiefsee-expedition. Wiss Ergebn Dt Tiefsee-Exped 4(22):125-266 [reprint 1-144]

Carlgren O, (1932) Die Ceriantharien, Zoantharien und Actiniarien des arktischen Gebietes. In: Gustav Fischer (ed) Fauna arctica. Jena 6:255-266

Carlgren O, (1933) Zoantharia and Actiniaria. The Godthaab Expedition 1928 Meddelelser om Gronland af Kommisionen for Videnskabelige undersogelser I Gronland Bd 79(8):155

Carlgren O, (1934) Zoology_-Some Actiniaria from Bering Sea and arctic waters J Wash Acad Sci 24(8):348-353

Carlgren O, (1940) A contribution to the knowledge of the structure and distribution of the cnidae in the Anthozoa Lunds Univ Aarssk N F adv 2 36(3):1-62

Carlgren O, (1942) Actiniaria II Danish Ingolf-Exp 5(12):1-92

Carlgren O, (1949) A survey of the Ptychodactiaria, Corallimorpharia and Actiniaria K. Svenska Vetenskapsakad Handl ser 4 $1(1): 1-121$

Danielssen DC, (1890) Actinida. In: Grøndahl, Søn, (eds) Den Norske Nordhavs-Expedition 1876-1878. Zoology. Christiania, p 184

Fautin DG, (2004) Hexacorallians of the world. http://hercules.kgs.ku.edu/hexacoral/anemone2/index.cfm (Version April 2004)

Gabe M, (1968) Technique Histologique. Massou et Cie, Paris

Gosse PH, (1858) Synopsis of the families, genera and species of the British Actiniae Ann Mag Nat Hist ser 3(1):414-419
Hand C, (1955) The Sea Anemones of Central California. Part III. The Acontiarian Anemones Wasmann J Biol 13(2):189-319

Haddon AC, (1898) The Actiniaria of Torres Straits Sci Trans R Dublin Soc ser 2(VI):393

Hertwig R, (1882) Report on the Actiniaria dredged by H.M.S. Challenger during the years 1873-1876 Sci Res Voy H.M.S. Challenger Zool 6(1):1-136

Johansen DA, (1940) Plant microtechniques. McGraw-Hill, New York London

Koren J, Danielssen DC, (1877) Description of some new Norwegian coelenterates. In: Sars M, Koren J, Danielssen DC, (eds). Fauna Littoralis Norvegiae. Bergen 3:77-81

Mariscal RN, (1974) Nematocysts. In: Muscatine L, Lenhoff HM, (eds). Coelenterate biology. Academic Press, New York, pp. $129-178$

Manuel RL (1988) British anthozoa. In: Kermack DM, Barnes RSK (eds) Synopses of the British fauna (new series) No 18 (Revised). Brill EJ/Backhuys Dr W, Leiden New York København Köln

Östman C, (2000) A guideline to nematocyst nomenclature and classification, and some note on the systematic value of nematocysts Sci Mar 64(1):31-46

Riemann-Zürneck K, (1991) The abyssal Sea Anemone Kadosactis sulcata Carlgren 1934 (Cnidaria: Actiniaria: Kadosactidae nov. fam.) Senckenbergiana marit 21(5/6):191-204

Schmidt H, (1969) Die Nesselkapseln der Aktinien und ihre differentialdiagnostische Bedeutung Helgoländer wiss Meeresunters 19:284-317

Schmidt H, (1972) Prodromus zu einer Monographie der mediterranen Aktinien Zoologica 42 2(121):120

Schmidt H, (1974) On evolution in the Anthozoa. In: Proceedings of the 2nd international coral reef. symposium, 1. Great Barrier Reef Committee, Brisbane, pp533-560

Stephenson TA, (1920) On the classification of Actiniaria Part I. Q J Microsc Sci 64:425-574, Cambridge

Stephenson TA, (1921) On the classification of Actiniaria Part II. Q J Microsc Sci 65:493-576, Cambridge

Stephenson TA, (1922) On the classification of Actiniaria Part III. Q J Microsc Sci 66:247-319, Cambridge 